\title{
Funkcjonalne naruszenia normy ortograficznej w memach internetowych
}

\author{
Agnieszka A. Niekrewicz \\ Wydział Humanistyczny, Akademia im. Jakuba z Paradyża w Gorzowie Wielkopolskim, \\ ul. Teatralna 25, 66-400 Gorzów Wielkopolski, Polska; \\ adres e-mail: aniekrewicz@pwsz.pl
}

\begin{abstract}
Abstrakt
Celem artykułu jest omówienie funkcjonalnych naruszeń zasad pisowni w memach internetowych. Autorka przedstawia przykłady stylizacji językowej charakterystycznej dla poszczególnych szablonów, której elementem jest naruszenie normy ortograficznej. Dowodzi związku zmian pisowni z charakterystyczną dla memów intencją deprecjonującą, a także z odtwarzaniem stereotypów osobowych. Ponadto pokazuje rolę modyfikacji pisowni w tworzeniu gier językowych i nowych znaczeń. Zanalizowane przykłady świadczą o dominacji funkcjonalnych odstępstw od normy nad rzeczywistymi błędami ortograficznymi. Brak zgodności z zasadami może być uznany za specyficzną formę aprecjacji poprawności językowej. Niepoprawność bowiem jest najbardziej wyrazistym środkiem służącym deprecjonowaniu polityków, celebrytów oraz przedstawicieli różnych grup społecznych, a jednocześnie wyrazem troski o kulturę języka.
\end{abstract}

Słowa kluczowe: mem internetowy; pisownia w komunikacji internetowej; ludyczność.

\begin{abstract}
The aim of this article is to discuss the functional violations of the spelling rules in online memes. The author presents examples of language styles characteristic of individual templates which breach the spelling rules. She demonstrates a relationship between the changes in spelling and the depreciating intention typical of memes as well as the repeated personal stereotypes. In addition, she shows the role of the spelling modifications in creating word games and new meanings. The analysed examples prove the dominance of functional deviations over genuine spelling mistakes. Non-compliance with the rules can be regarded as a specific form of appreciation of language correctness. Incorrectness is the most prominent means to depreciate politicians, celebrities and representatives of various social groups, at the same time reflecting concern about the culture of the language.
\end{abstract}

Keywords: online meme; spelling in online communications; play.

Mem internetowy stanowi kompozycję złożoną na ogół zarówno ze znaków werbalnych, jak i wizualnych, przekazywaną i modyfikowaną za pośrednictwem sieci. Postrzeganie gatunku jest w dużym stopniu zdeterminowane przez teorię Richarda Dawkinsa (1996), twórcę ewolucyjnej koncepcji kultury. W większości opracowań pisze się o ,zaraźliwości” memów internetowych, która łączy je z jednostkami kulturowego przekazu wyodrębnionymi przez 
R. Dawkinsa, a ich kopiowanie oraz modyfikowanie uznaje się za potwierdzenie tego oddziaływania.

Memetyczna „zaraźliwość” objawia się przede wszystkim w nierespektującym praw autorskich powielaniu obrazów i słów. Jest tożsama z wykorzystywaniem utrwalonych szablonów, wiernym lub swobodnym powtarzaniem konceptów, parafrazowaniem, parodiowaniem - oznacza zatem konstruowanie nowej wypowiedzi z elementów użytych wcześniej, uznawanych za atrakcyjne, często zakorzenionych w świadomości językowo-kulturowej.

Powtarzalność jest nieodłączną cechą memów opartych na szablonach, tj. wzorcach określających obraz, treść oraz formę części werbalnej. Schematy tego rodzaju, zwykle określone przez twórców pierwszych memów z danego wzorca, mogą być zwerbalizowane we wstępnej charakterystyce szablonu albo mieć charakter niepisanej umowy. W tym drugim przypadku „zaraźliwość” jako podstawowa cecha gatunku memetycznego manifestuje się najwyraźniej, ponieważ internauci z własnej inicjatywy naśladują język i treść memów, które wywarły na nich wpływ.

Do zbioru językowych cech często powtarzanych przez internautów należy naruszanie norm poprawnościowych oraz zasad pisowni i interpunkcji. Powszechność skłania do rozważenia gatunkowej konstytutywności tej cechy języka memów. Odrzucenie zasad poprawnościowych, przede wszystkim ortograficznych, jest rzeczywiście obligatoryjne w przypadku niektórych szablonów memetycznych (takich jak „CoJaPacze”; „Babcia okienna”; „Komorofzki”)1. Realizacja schematu wymaga albo dowolnego odstępstwa od normy, albo powtarzania błędów określonego typu, np. niepoprawnego zapisywania zbitek spółgłoskowych (szablon „CoJaPacze”) czy modyfikowania formy związków frazeologicznych (szablon „Zjarany Zbyszek”). Badanie znaczącego statystycznie zbioru memów wykazało jednak przewagę kompozycji, których część werbalna jest w pełni poprawna (Niekrewicz 2015b). Z drugiej strony należy podkreślić ogromną popularność memów zawierających błędy językowe, stylistyczne oraz ortograficzne. Niezgodne z normą wypowiedzi memetyczne często stają się punktem wyjścia do prowadzenia gry słownej w kolejnych memach. Takie wewnątrzgatunkowe nawiązania przyczyniają się do tworzenia serii memetycznych, których składniki wchodzą ze sobą w nieustanne relacje. Nierozpoznanie odwołań zmienia znaczenie memu lub czyni go niezrozumiałym, np. modyfikacje wyrazów prowadzące do wyodrębnienia morfemu „pacz” wymagają identyfikacji związku z protomemem przedstawiającym kota, który swoje zdumienie wyraża pytaniem Co ja pacze?

Celem artykułu jest określenie funkcji naruszeń zasad pisowni w memach internetowych. Punkt wyjścia stanowi założenie, że większość twórców memów, których część werbalna jest zapisana niepoprawnie, świadomie i w określonym celu odrzuca reguły ortograficzne i interpunkcyjne. Świadczy o tym przede

1 Tytuły szablonów, na podstawie których tworzone są memy układające się w serie tematyczne. 
wszystkim istnienie wyraźnego związku między szablonami memetycznymi a (nie)poprawnością zapisu. Ponadto memy zawierające błędy należą do najpopularniejszych, najczęściej powielanych lub modyfikowanych, mimo że nie mają przewagi ilościowej w zbiorze memów traktowanych jako odrębne, jednostkowe wypowiedzi. Celowe naruszanie normy jest podporządkowane różnym intencjom (np. grze słownej, charakterystyce postaci, prowokacji, zwróceniu uwagi odbiorcy etc.).

Przyjęcie założenia memetyki utożsamiającej twórców z osobami kopiującymi i udostępniającymi memy nie pozwala na statystyczną weryfikację popularności memów. Kompozycje o największej sile oddziaływania mogą bowiem istnieć w milionach kopii udostępnianych na milionach stron, inne - mają charakter jednostkowy, nie są powielane wcale. Ze względu na zasięg sieci ustalenie liczby krążących w niej kopii jest niemożliwe, a traktowanie każdego memu jako jednostki doprowadziłoby do zrównania najbardziej znanych memów (np. Co ja pacze; Sorry, taki mamy klimat) z tworami nieudanymi, często pustymi semantycznie, nielogicznymi, które nie wyszły poza generator albo zostały opublikowane na prywatnym blogu.

Istotny problem metodologiczny stanowi również oddzielenie nieświadomych, przypadkowych naruszeń zasad pisowni (wynikających np. z ignorancji, nieznajomości reguł lub niedbałości) od zamierzonych zabiegów o charakterze funkcjonalnym. Pomocne może być założenie, że świadome innowacje dominują w memach opartych na schematach określających sposób ukształtowania części językowej. Powielanie w nich błędów jednego typu, realizujących identyczny mechanizm, skłania do uznania ich za wynik zamierzonych zabiegów. Bardziej dyskusyjne mogłoby okazać się zastosowanie kryterium funkcjonalnego, sformułowanego przez Halinę Kurkowską (1986: 11-79). Według badaczki te przekroczenia normy, które służą pełnieniu funkcji komunikatywnej, są innowacjami przydatnymi funkcjonalnie, nie stanowią zatem błędów językowych. Intencjonalność naruszenia normy w memach internetowych nie zawsze jednak jest tożsama $\mathrm{z}$ funkcjonalnością. Wiele zabiegów ma charakter nieprzemyślany i niespójny, nie w pełni zgodny z wytycznymi wpisanymi w dany schemat. Nieznajomość normy utrudnia autorom memów jej funkcjonalne naruszenie, ale intencja nie pozwala w tych przypadkach mówić o błędach językowych, a co najwyżej o błędnym zastosowaniu reguł szablonu określającego typ przekroczenia normy².

2 Szablony memetyczne mogą narzucać określony sposób kształtowania warstwy językowej, w tym zgodności z normami poprawnościowymi. Na przykład memy wykorzystujące wizerunek prezydenta Bronisława Komorowskiego są podpisywane w sposób sprzeczny z zasadami ortografii; część werbalna memów z postacią zaskoczonego kota jest zapisywana tak, by oddać szerzące się błędy fonetyczne; w memach opartych na autoportrecie Josepha Ducreux oraz wizerunku Mistrza Yody umieszcza się zdania o odwróconym szyku wyrazowym. Więcej na ten temat zob. Niekrewicz $2015 \mathrm{a}$. 


\section{Stylizacja o funkcji charakteryzującej}

Szablony określają temat, styl i język opartych na nich memów. Jedną z częstych cech wypowiedzi utworzonych na podstawie szablonów jest naruszanie zasad poprawnościowych. Na ogół można je traktować jako zabieg o charakterze stylizacji mającej oddawać cechy idiolektu lub socjolektu osoby widniejącej na fotografii. Stylizacja ta ma szczególny charakter, ponieważ jest dziełem wielu autorów, których zwykle dzieli bardzo dużo, np. pomysłowość, wyczucie stylistyczne, poczucie humoru, wiedza o kulturze, znajomość norm poprawnościowych, a łączy jedynie wybór schematu. Na płaszczyźnie leksykalno-frazeologicznej wypowiedzi memetyczne stanowią konglomeraty frazemów przypisanych poszczególnym szablonom oraz środków stanowiących indywidualne realizacje systemu. Podobnie w zapisie, odstępstwa od zasad ortograficznych i interpunkcyjnych wynikające z podporządkowania regułom schematu łączą się z typowymi błędami, których przyczyną jest nieuwaga lub niewiedza autora. Powtarzalność błędów danej kategorii pozwala na oddzielenie elementów pomyślanych jako środki służące stylizacji od niezamierzonych naruszeń zasad, czyli rzeczywistych błędów.

Świadome odstępstwa od zasad pisowni pojawiają się przede wszystkim w szablonach o charakterze deprecjonującym. Są wprowadzane do wypowiedzi polityków, celebrytów i anonimowych osób traktowanych jako stereotypowi reprezentanci różnych środowisk i grup społecznych, np. starszych kobiet, kasjerek, gimnazjalistów, narkomanów, pijaków, kibiców etc. Paradoksalnie, błędy przypisywane bohaterowi memetycznemu, którego twórca poddaje negatywnemu wartościowaniu, można traktować jako sposób aprecjacji poprawności językowej-jej brak jest bowiem jednym z najbardziej wyrazistych środków deprecjonujących.

W wypowiedziach staruszek (np. szablony „Babcia okienna”, „Baba z zieleniaka”, „Pierwsze internety babci”) zapis niezgodny z zasadami ma odzwierciedlać niepoprawną wymowę, ujawniającą naleciałości gwarowe, a także dowodzącą wyobcowania ze współczesnego świata - zwłaszcza przejawiającego się nieznajomością nowoczesnej technologii. Autorzy wypowiedzi memetycznych realizujących wskazane szablony nie starają się naśladować konkretnego dialektu, ale odzwierciedlają najczęstsze cechy wymowy, nierzadko o charakterze ogólnodialektalnym lub mające genezę regionalną, lecz obecne także w niestarannej polszczyźnie ogólnej, np. denazalizację w wygłosie, uproszczenia polegające na pomijaniu głosek, dwuelementową wymowę samogłoski $a$ w wygłosie oraz przed spółgłoskami szczelinowymi, rzadziej prelabializację oraz zmiękczanie spółgłosek tylnojęzykowych $k$ i $g$ przed samogłoską $e$. Typowe jest również zniekształcanie wyrazów obcego pochodzenia.

Stylizacja językowa łączy się z uwydatnianiem na płaszczyźnie semantycznej stereotypowych cech kojarzonych z określonymi typami osobowymi. W rezultacie na przykład bohaterkom szablonów „Baba z zieleniaka” oraz „Babcia okienna" przypisuje się opryskliwe wypowiedzi zapisane w sposób odzwierciedlający niepoprawną lub po prostu niestaranną wymowę: Wejdo, nabłoco, nic nie kupio 
i wyjdo; Dzie z butami?; Na Owsiaka to dajo tudstokowce jedne; Ledżinsy, jakie ledizinsy?! Spódnicy zapomniała, dupa świeci!; Pod sklepem tylko pijo. Piniondze wytudzajo; $W$ pitke grajo. Zara tokno wybijo; Na dyskotekie $w$ wielki post ido. Szatańskie pomioty; Minusy przy memach dajom. A same za robote sie nie wezmom; Pisiont groszy podnosi, ale na tace potem nie da; Stojo i sie cieszo. Maruchainy sie pewno nawąchali; Tańczo, pijo, lulki palo. A toyoty księdzu umyć, to ni ma komu itd.

W wypowiedziach umieszczanych pod wizerunkiem stereotypowego polskiego turysty pojawiają się zapożyczenia (głównie o charakterze cytatów) zapisane fonetycznie w sposób odzwierciedlający nieznajomość właściwej wymowy. Z grafią współgra treść komunikatów świadcząca o skąpstwie, wąskich horyzontach, braku zainteresowania obcą kulturą oraz ograniczaniu wakacyjnej aktywności do prostych rozrywek, np. Nie moge gadać na rolamingu jestem; Jesteśmy $w$ tej Turcji, mamy ol ikluziw. A na śniadanie parówek nie ma!; Grażyna, dawaj do baru. Sam tego al inklusif nie wychlam; Gdzie sa te krawatki, homary i ostrogi? Mamy olinklusyf; Grażyna, idziemy na arełobik. Zapłacone, to trzeba korzystać.

Stylizacja o funkcji deprecjonującej dominuje w memach, których bohaterami są osoby starsze. Analiza treści i formy memów tego typu pozwala założyć, że ich twórcy to osoby bardzo młode, które negatywnie wartościują tradycjonalizm starszego pokolenia, utożsamiając go z komicznym wyobcowaniem ze współczesnego świata. Znacznie rzadziej deprecjacja wyrażona na poziomie pisowni dotyka osoby młode. Błędne zapisy nazw własnych i innych wyrazów są umieszczane m.in. w memach opartych na szablonie „Ignorancka gimnazjalistka”. Współtworzą one ironiczną ocenę nastolatki pewnej siebie, ale pozbawionej elementarnej wiedzy o świecie, np. Uwielbiam duety. Mój ulubiony to Eurique I Glesias; Równania? Nie umię, jestem chumanistka. Z kolei wypowiedzi przypisywane blokersowi zwanemu „Typowym Sebą” zawierają modyfikacje pisowni odzwierciedlające zniekształcenia charakterystyczne dla niestarannej wymowy oraz fonetycznie zapisane wyrazy obce, np. Jaki fall. Czysto w pile byo; Kryj supek; Mati, puść eksplotżyn. Laski idom; Ide na solo. Mati, czymaj plecak; Ja tera nie ide. Zara mam obiad.

Naruszanie zasad pisowni jest powszechnym zabiegiem o funkcji charakteryzującej w memach, których bohaterami są politycy. Można go odczytywać jako demaskację niekompetencji językowej, która w wyniku zestawienia z nielogiczną i absurdalną treścią wypowiedzi ma być dowodem na brak przygotowania jej nadawcy do pełnienia funkcji publicznych. W wielu memach niepoprawny zapis determinuje negatywne wartościowanie komunikatów, które w przypadku zachowania zgodności z zasadami miałyby wydźwięk pozytywny lub przynajmniej neutralny. Modyfikacja pisowni staje się zatem sposobem wyrażania poglądów politycznych oraz kwestionowania tez i opinii.

Zmiany w pisowni mogą dotyczyć wypowiedzi wszystkich polityków, z którymi autor memu się nie zgadza lub których po prostu nie darzy sympatią. Najczęściej jednak w ten sposób zapisywane są zdania umieszczane pod wizerunkiem 
prezydenta Bronisława Komorowskiego, który od czasu ujawnienia przez media niepoprawnego ortograficznie wpisu do księgi kondolencyjnej Ambasady Japonii funkcjonuje w sieci jako uosobienie dysortografika. Znaczącą rolę w kształtowaniu takiego wizerunku prezydenta Komorowskiego odegrało powstanie szablonów memetycznych „Komorofzki” i „Mściwy Bronisuaf”. Przejście od nagłośnionego $\mathrm{w}$ mediach wydarzenia do ukształtowanego na jego podstawie uogólniającego przekonania jest przykładem charakterystycznej dla memów nadinterpretacji oraz intensyfikacji. Trudno wskazać przyczyny, dla których niektóre zdarzenia lub sytuacje stają się wielokrotnie przetwarzanym tematem memów, a inne pozostają niezauważone. Niewątpliwie jednak te, które trafiają na memetyczny warsztat, są poddawane hiperbolizacji oraz innego rodzaju swobodnym przeróbkom, które służą formowaniu jednostronnego, schematycznego wizerunku danej postaci. Nagłośnienie przez media błędów popełnionych przez prezydenta Komorowskiego wystarczyło, by niepoprawny zapis stał się nieodłączną cechą jego memetycznych wypowiedzi, dezawuującą ich wartość, a ich autor otrzymał stały przydomek $B u l^{3}$.

W memach wykorzystujących wizerunek prezydenta Komorowskiego pojawiają się niemal wszystkie typy błędów pisowni: spowodowane brakiem we współczesnej wymowie różnicy między $h \mathrm{i} c h, \dot{z}$ i $r z, o ́$ i $u$, wynikające z utożsamienia pisowni z wymową (np. nieoznaczanie nosowości ę występującego w wygłosie, zastępowanie głosek dźwięcznych przed pauzami głoskami bezdźwięcznymi, zapisywanie w sposób jednolity grup spółgłoskowych - jako bezdźwięczne lub dźwięczne, oddawanie asynchronicznej wymowy samogłosek nosowych przed spółgłoskami zwartymi, zapis fonetyczny anglicyzmów) oraz dowodzące nieznajomości zasad pisowni łącznej i rozłącznej ${ }^{4}$, np. Emerytura od 67 l.? Rzal i bul; Morze i robię blendy ale zarabiam wiencej $w$ miesionc nisz ty w caty rok; Tak nam dopomusz Buk!; Rzegnam jusz was!; Jak cipo szedl egzamin $?^{5}$ Podobnie jak w innych szablonach deprecjonujących stosowane są niepoprawne ortograficznie zapisy odtwarzające niezgodną $\mathrm{z}$ normą wymowę: nadmierne uproszczenia grup spółgłoskowych, niewłaściwą realizację nosówek w wygłosie, niewyraźną wymowę spółgłosek półotwartych oraz nieprawidłową wymowę zapożyczeń, np. Piersza zasada sawular wiwru; Ras się człowiek pomyli i się śmiejom całe życie; Jadem na Ókrajine. Bendom jaja; Miasto na dwie litery? Ú⿱㇒́ $;$ Pacz Anka.

3 Przydomek motywowany treścią niepoprawnego wpisu prezydenta do księgi kondolencyjnej Ambasady Japonii: „,w bulu i nadzieji”. Zob. np. www 1. W nawiązaniu do utrwalonego przydomka Bronisława Komorowskiego jego przeciwnika politycznego, Andrzeja Dudę, twórcy memów nazwali środkiem ,przeciw-bulowym”.

${ }^{4}$ Ze względu na powszechne zapisywanie wypowiedzi memetycznych wersalikami stosunkowo rzadko można wskazać błędy polegające na niewłaściwym użyciu wielkich i małych liter.

${ }^{5}$ Podział graficzny stanowi jednocześnie przykład gry językowej pozwalającej na uzyskanie wieloznaczności zdania. 
Memetyczna skłonność do przesady widoczna jest w popełnianiu błędów skrajnie nieprawdopodobnych, nieodzwierciedlających ani poprawnej, ani błędnej wymowy, lecz polegających na tworzeniu zbitek głoskowych niemożliwych lub trudnych do wymówienia. Odstępstwa od normy są nieprzemyślane, wprowadzane przez osoby, które nie znają mechanizmów leżących u podstaw błędów ortograficznych lub ich nie uwzględniają. Celem nadrzędnym jest intensyfikacja danej cechy (nawet za cenę zachwiania prawdopodobieństwa) podporządkowana intencji deprecjonującej. Nierzadko więc politykom przypisuje się wypowiedzi trudne do odczytania, zawierające błędy nieoparte na żadnych konkretnych mechanizmach, np. Nona reszće. Barżdż z urzkami (Bronisław Komorowski); Sondze. Rze Acta zrobi z fami pożontek (Bronisław Komorowski); Jestę gotabię (Andrzej Duda); Jak moszna nie szanowadźpolsgieko języka? (Bronisław Komorowski).

Autorzy memów dążą do graficznego oddania charakterystycznej wymowy polityków, np. niewłaściwej artykulacji $r$ czy naleciałości gwarowych lub regionalnych. Tak jak w przypadku wyżej omówionych memów nie obowiązuje ścisła reguła określająca sposób graficznego oznaczania cech artykulacyjnych. Niewłaściwa wymowa głoski $r$ może być odzwierciedlana za pomocą liter $h, l, l$ oraz $u$, np. Z plezesa Jalostawa to taki Zollo jak ze mnie Lobin Hood (Hanna Gronkiewicz-Waltz); Bhonek ty wahiacie. Aleś ty hadykalny (Hanna Gronkiewicz-Waltz); Vat na żauty z puemieua (Donald Tusk); Gowin będzie plemietem (Donald Tusk). Brak konsekwencji w graficznym ilustrowaniu niepoprawnej wymowy widać w zapisie jednego z najbardziej znanych zdań wypowiedzianych przez prezydenta Lecha Wałęsę „Nie o taką Polskę walczyłem”. Jego popularność wynika z powszechnej w memach ekspresji uczuć negatywnych, zwłaszcza niezadowolenia i oburzenia. W rezultacie frekwencja zdania, łączonego w memach z krótkimi wypowiedziami uzasadniającymi opinię, jest bardzo wysoka. Internauci podkreślają niewłaściwą realizację samogłosek nosowych w wygłosie w zróżnicowany sposób, np. Nie o takom Polskie walczyłem; Nie o takie Polskie walczyłem; Nie o take Polske walczyłem; Nie o tak Polsk walczyłem.

Szablony o treści politycznej deprecjonują poprzez sugerowanie nieznajomości zasad ortograficznych i właściwych postaci fonetycznych wyrazów. Umieszczone pod fotografiami osób publicznych są odczytywane jako demaskacja ich językowej niekompetencji, nawet jeżeli nie sposób potwierdzić naruszania przez nie norm w rzeczywistości. W szablonach podporządkowanych krytyce obyczajowej niezgodna z normą pisownia odzwierciedla głównie niewłaściwą wymowę, jednocześnie uwydatniając ośmieszane $\mathrm{w}$ treści stereotypowe cechy zachowania.

${ }^{6}$ Zdanie wygłoszone 11 marca 2013 r. w programie TVP 2 „Tomasz Lis na żywo”, stanowiące modyfikację dawnej wypowiedzi Lecha Wałęsy „O take Polskę walczyłem”, http://www.tvp. info/10376813/informacje/polska/lech-walesa-rozgoryczony-sytuacja-w-kraju/ [dostęp: 13.06.2015]. Właściwie: „Nie jestem rozgoryczony aż tak, ale to wszystko... nie o taką Polskę walczyłem. I nie o takie efekty, jakie na dzisiaj są". 


\section{Funkcja ludyczna innowacji ortograficznych}

Zapis niezgodny z zasadami jest cechą typową dla memów określanych mianem lolkotów (ang. lolcat - LOL 'śmiać się głośno" + cat 'kot'). Jak wskazuje nazwa, ich bohaterami pierwotnie były koty, wtórnie - także inne zwierzęta, mówiące wprawdzie językiem ludzi, ale popełniające liczne błędy gramatyczne i fonetyczne (np. Co ja pacze?; Co ja czepie?; Co ja zycze?; Co ja skaczem, na co ja paczem?; F twoich dokumentah... ...szukawszy miejsca na swoja tlusta dupe). Efekt komiczny byłby jednak niewielki, gdyby ograniczał się tylko do zniekształcenia wypowiedzi, która w odniesieniu do zwierząt nie może pełnić funkcji deprecjonującej, charakterystycznej dla większości memów zapisanych niezgodnie $\mathrm{z}$ zasadami. Istotne jest zatem modyfikowanie pisowni tak, by dawała odbiorcy satysfakcję płynącą z rozpoznania związku z innymi lolkotami, a jednocześnie wyrażanie nowych treści wykraczających poza schemat. W memach tego typu zmiany w pisowni łączą się z naruszaniem normy językowej w zakresie składni, fleksji i leksyki. Zwierzęcy bohaterowie memów stają się wyrazicielami krytyki społeczno-politycznej oraz obyczajowej. Walczą z porozumieniem ACTA (ACTA wie, że paczysz; Dzie ja siedze? W pacze siedze. Za paczenie; Jak wprowadza ACTA, nie będzie na co paczeć), piętnują nieudolność polityków (Co ja partacze) i urzędników (Rozpaczam twój wniosek; Mój mem czeka na rozpaczenie), ośmieszają typowe zachowania, zwłaszcza te uznawane za przejaw mody (Jestę faszionelką ; Sie ćwiczyo) etc.

Elementem współtworzącym komizm lolkotów są zabiegi o charakterze intertekstualnym. Zwierzęcym bohaterom przypisuje się zmodyfikowane i niepoprawnie zapisane cytaty literackie, filmowe, muzyczne lub historyczne, np. Paczeć, czy nie paczeć. Oto jest pytanie ${ }^{8}$; Czymaj mnie!! Bo nie wyczymie!!'; Co ja pacze tu? Uиuи Co ty tutaj paczysz? ииии ${ }^{10}$; Przybytem. Popaczytem. Zwyciężytem ${ }^{11}$.

Bez wątpienia znacząca większość modyfikacji tego rodzaju nawiązuje do zawierającego błąd ortograficzny, leksykalny i składniowy pytania Co ja pacze?, które przyniosło polskim lolkotom ogromną popularność. Druga pod względem liczebności grupa zniekształceń pisowni obejmuje zmiany odzwierciedlające niepoprawną wymowę zbitki spółgłoskowej [tš] oraz [stšs]. W tym przypadku związek z memami tzw. nurtu paczaistycznego jest nadal aktualizowany, chociaż już nie tak wyraźny, np. Obudziłem się w nocy. Była czecia czydzieści; Bytem w toalecie za poczeba; Czecia czynaście? Czeba wyczepać dywan; Szczeżonego Pan Bóg szczeże. Jeśli założyć, że koty i inni zwierzęcy bohaterowie memów są alego-

7 Fashionelka/faszionelka 'blogerka modowa'.

${ }^{8}$ Właściwie: „Być albo nie być; oto jest pytanie”, W. Szekspir, Hamlet, przeł. M. Słomczyński.

9 Właściwie: „Ludzie, trzymajcie mnie, bo nie wytrzymam!”, wypowiedź K. Pawlaka z filmu Kochaj albo rzuć, reż. S. Chęciński. Wypowiedź ma charakter frazematyczny, jednak w tym przypadku identyfikację prototekstu umożliwia kadr ze wskazanego filmu.

${ }^{10}$ Właściwie: „Co ja robię tu? Uu. Co ty tutaj robisz?”, wyk. Elektryczne Gitary.

11 Właściwie: „Przybyłem. Zobaczyłem. Zwyciężyłem”, Gajusz Juliusz Cezar, 47 r. p.n.e. 
riami ludzkich postaw, cytowane wypowiedzi byłyby nie tylko formą językowej gry, ale także środkiem służącym ośmieszeniu współczesnej tendencji artykulacyjnej.

Naruszanie zasad pisowni w lolkotach pełni dodatkowo funkcję jednoczącą członków wspólnoty nadawców i odbiorców memów internetowych. Błędy ortograficzne są traktowane jako konstytutywna cecha memów tej grupy. Podjęcie gry językowej polegającej na ignorowaniu reguł poprawnościowych zgodnie z zasadą memetycznego szablonu jest więc traktowane jako warunek przynależności do sieciowej społeczności. Świadczą o tym m.in. komentarze wartościujące negatywnie wypowiedzi zawierające propozycje poprawy błędów, np. Jakie patrzę? Ktoś tu nie umie pisać; Chyba dźwi! Pisać nie umisz.

Zmiany pisowni mogą również współistnieć z leksykalnymi zabiegami komizmotwórczymi, np. upodobnieniami, dekompozycjami oraz pseudoetymologizacją. Powszechność zapisów odbiegających od normy pozwala na kojarzenie ze sobą wyrazów nie w pełni tożsamych brzmieniowo czy graficznie. Wystarczy częściowe podobieństwo, by uruchomić asocjacje i na ich podstawie zbudować przekaz semantyczny. Zabiegi tego rodzaju są wykorzystywane m.in. w memach o tematyce politycznej. Uzyskana za ich pomocą dwuznaczność wypowiedzi pozwala na zdemaskowanie ukrytych intencji lub nieujawnianych cech mówiącego. W rezultacie np. słowa przypisane przewodniczącemu PiS Jarosławowi Kaczyńskiemu PiS da a nie demokracja mogą być odczytywane zarówno jako obietnica wyborcza, jak i wulgarna diagnoza sytuacji politycznej. Słowa Krystyny Pawłowicz Walczę zażarcie można uznać za deklarację heroicznej postawy lub nawiązanie do ujawnionego przez media zachowania posłanki $\mathrm{w}$ trakcie sejmowych obrad $^{12}$. Wypowiedź Donalda Tuska Nie ma ludzi idealnych. Ja też nie jestem bez vat może być traktowana jako niepoprawnie zapisane podkreślenie ludzkiej niedoskonałości lub żartobliwe nawiązanie do podwyższenia stawek podatku VAT, które w memach stało się jednym z podstawowych zarzutów stawianych Platformie Obywatelskiej i jej liderowi. W rezultacie także zapisywanie morfemu „wat” jako vat przybrało formę powtarzalnego schematu realizowanego konsekwentnie w memach z fotografią Donalda Tuska. Zapisane w ten sposób wypowiedzi niezależnie od tematu mogą być zatem odczytywane jako krytyka programu podatkowego Platformy Obywatelskiej.

Swobodne traktowanie reguł pozwala na mieszanie elementów rodzimych i obcych w obrębie jednej wypowiedzi, a nawet jednego wyrazu. Innowacje ortograficzne - polegające na zapisywaniu wyrazów polskich według angielskich reguł fonetycznych lub odwrotnie, wyrazów angielskich tak jak zapisałby je nieznający angielszczyzny Polak - często są nieprzypadkowe, podporządkowane funkcji semantycznej. W memach z wizerunkiem Donalda Tuska stanowią aluzję do publicznie akcentowanej nauki języka angielskiego i zarazem są kpiną z pozio-

${ }^{12}$ W grudniu 2014 r. Krystynie Pawłowicz zarzucono spożywanie posiłku w trakcie obrad Sejmu. Zachowanie posłanki wywołało polityczną awanturę i stało się popularnym tematem memów. 
mu jego znajomości, np. Bronek ja ci powiem. Idź na the batę. W memach realizujących określony szablon służą aktualizacji stereotypowej cechy danej postaci. W serii z Bronisławem Komorowskim można je uznać za kontynuację memetycznego programu ośmieszania niskiej kompetencji językowej byłego prezydenta, np. Komorowski: Mam taka gruba książę do angielskiego. Obama: What? Komorowski: tot żony... Z kolei na tle fotografii Aleksandra Kwaśniewskiego zamiast angielskiego przekleństwa What the fuck umieszczono jego modyfikację Wód the fuck, wprawdzie niedokładnie odzwierciedlającą obcą wymowę, ale za to wpisującą się w nurt przedstawiania byłego prezydenta jako imprezowicza i alkoholika.

Modyfikacje pisowni o funkcji ludycznej trudno oddzielić wyraźnie od gier słownych opartych na mechanizmach leksykalnych. Innowacje tego rodzaju są wykorzystywane powszechnie jako narzędzie satyry w memach politycznych.

\section{Podsumowanie}

Pojawienie się nowego gatunku - memu internetowego przyczyniło się do intensyfikacji naruszania zasad ortograficznych w sieci. Znaczną część tych naruszeń stanowią zabiegi, których celowość znajduje potwierdzenie w konsekwentnym powtarzaniu zmian określonych przez szablon, nagromadzeniu odstępstw od normy w obrębie jednej wypowiedzi, braku prawdopodobieństwa zapisów niezgodnych z regułami fonetyki lub wręcz niemożliwych do wymówienia, a także współtworzeniu sensów naddanych.

Funkcje innowacji ortograficznych są zróżnicowane. Swobodne traktowanie reguł może być rodzajem gry słownej - służącej uruchamianiu nowych znaczeń lub stanowiącej rodzaj antytradycjonalistycznej prowokacji, być może także sposób na zamanifestowanie wolności, z którą powszechnie kojarzony jest Internet. Często ma charakter zabiegu o charakterze stylizacji, której celem jest oddanie typowych cech wymowy lub podkreślenie niekompetencji językowej. $\mathrm{W}$ ten sposób niepoprawność w zakresie pisowni lub gramatyki staje się najbardziej wyrazistym środkiem deprecjonującym, a jednocześnie wyrazem troski o kulturę języka. Powielanie powszechnych błędów gramatycznych i fonetycznych oddawanych za pomocą grafii można uznać za metatekstową drwinę z niepoprawności i niestaranności tekstów internetowych oraz wypowiedzi mówionych współczesnych Polaków. W części przypadków naruszanie zasad jest zabiegiem służącym zwróceniu uwagi odbiorcy lub po prostu wynikającym z pozbawionego dodatkowych funkcji naśladowania wymogów szablonu narzucającego łamanie reguł, w tym - jak w przypadku lolkotów - również wzorca obcojęzycznego. Naruszanie reguł ortograficznych może być także elementem wielopoziomowej gry językowej, w której modyfikacje graficzne łączą się z zabiegami o charakterze leksykalnym, słowotwórczym czy intertekstualnym. 


\section{WYKAZ ŹRÓDEL}

[dostęp: 12.03.2015]

„Fabryka Memów”, http://fabrykamemow.pl/

„Hipsterski Maoizm”, https://www.facebook.com/hipsterski.maoizm?fref=ts

„Kwejk”, kwejk.pl

„Memgenerator”, http://pl.memgenerator.pl/

„Memowisko", https://www.facebook.com/memowisko?fref=ts

„Memy”, http://memy.pl/

„Paczaizm”, https://www.facebook.com/PaczaizmPL?fref=ts

„Polityczne Memy”, https://www.facebook.com/PolityczneMemy

\section{Bibliografia}

(www 1) Komorowski łaczy się,,w bulu i nadzieji” z Japończykami, „Wprost”, 18.03.2011, http://www.wprost.pl/ar/236287/Komorowski-laczy-sie-w-bulu-i-nadzieji-z-Japonczykami/ [dostęp: 12.03.2015].

Dawkins R., 1996, Samolubny gen, przeł. M. Skonieczny, Warszawa.

Kamińska M., 2011, Uwaga, zaraźliwe memy! Perypetie znaku w Internecie, w: M. Kamińska, Niecne memy. Dwanaście wyktadów o kulturze Internetu, Poznań, s. 57-73.

Kurkowska H., 1986, Teoretyczne zagadnienia kultury języka, w: D. Buttler, H. Kurkowska, H. Satkiewicz, Kultura języka polskiego. Zagadnienia poprawności gramatycznej, Warszawa, s. 22-45.

Niekrewicz A., 2015a, Językowe sposoby zbiorowego kreowania typów bohaterów w memach internetowych, w: Zielonogórskie Seminaria Językoznawcze 2014: Język w życiu wspólnoty, red. M. Hawrysz, M. Uździcka, A. Wojciechowska, Zielona Góra, s. 117-130.

Niekrewicz A., 2015b, Od schematyzmu do kreacyjności. Język memów internetowych, Gorzów Wielkopolski. 
